\title{
Pengaruh Gaya Kepemimpinan dan Pemanfaatan Teknologi Informasi pada Kualitas Laporan Keuangan Desa
}

\author{
I Gede Teo Basudewa ${ }^{1}$ \\ Fakultas Ekonomi dan Bisnis \\ Universitas Udayana, Indonesia \\ Email: teo.basudewa@gmail.com
}

\author{
I G. A. M. Asri Dwija Putri ${ }^{2}$ \\ Fakultas Ekonomi dan Bisnis \\ Universitas Udayana, Indonesia
}

\begin{abstract}
ABSTRAK
Tujuan dari penelitian ini adalah untuk mengetahui pengaruh gaya kepemimpinan dan pemanfaatan teknologi informasi pada kualitas laporan keuangan desa. Penelitian ini dilakukan di seluruh desa di kota Denpasar. Jumlah desa yang digunakan sebanyak 27 desa danjumlah sampek yang digunakan 180 orang, dengan metode purposive sampling responden dipilih harus mengetahui pengelolaan dana desa. Teknik analisis yang digunakan adalah regresi linear berganda. Berdasarkan analisis yang ditembukan bahwa gaya kepemimpinan dan pemanfaatan teknologi informasi berpengaruh positif terhadap kualitas laporan keuangan desa. Pemanfaatan Teknologi Informasi berpengaruh positif dansignifikan Terhadap Kualitas Laporan Keuangan Desa.
\end{abstract}

Kata Kunci: Gaya Kepemimpinan; Pemanfaatan Teknologi Informasi; Kualitas Laporan Keuangan Desa.

\section{The Effect of Leadership Style and Utilization of Information Technology on the Quality of Village Financial Statements}

\begin{abstract}
The purpose of this study was to determine the effect of leadership style and the use of information technology on the quality of village financial reports. This research was conducted in all villages in the city of Denpasar. The number of villages used is 27 villages and the number of sampels used is 180 people, with the purposive sampling method the respondents chosen must know the management of village funds. The analysis technique used is multiple linear regression. Based on the analysis revealed that the leadership style and the use of information technology have a positive effect on the quality of village financial reports. The use of information technology has a positive and significant effect on the quality of village financial reports.
\end{abstract}

Keywords: Leadership Style; Utilization of Information Technology; Quality of Village Financial Reports.

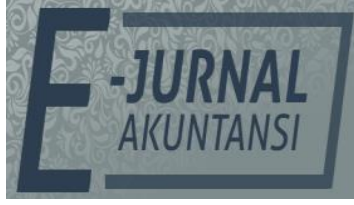

E-JA

e-Jurnal Akuntansi e-ISSN 2302-8556

Vol. 30 No. 7

Denpasar, Juli 2020

Hal.1658-1669

Artikel Masuk: 6 Maret 2020

Tanggal Diterima:

9 Juni 2020

This Article is Avalilable in: https://ojs.unud.ac.id/index.php/Akuntansi/index 


\section{PENDAHULUAN}

Pemerintah Indonesia menerbitkan Undang - Undang No 6 Tahun 2014, tentang Desa. Berdasarkan data pemerintahan Denpasar terdapat beberapa desa yang berada di Denpasar dan dana desa di setiap desa. Dalam peraturan Walikota Denpasar Nomor 10 Tahun 2018 pasal 1 ayat 6 Tentang Desa adalah desa dan desa adat atau yang disebut dengan nama lain, selanjutnya disebut desa, adalah kesatuan masyarakat hukum yang memiliki batas wilayah yang berwenang untuk mengatur dan mengurus urusan pemerintahan, kepentingan masyarakat setempat berdasarkan prakarsa masyarakat setempat, hak asal usul, atau hak tradisional yang diakui dan dihormati dalam sistem pemerintahan Negara Kesatuan Republik Indonesia. Adanya Dana Desa bertujuan untuk meningkatkan pembangunan desa, memajukan perekonomian desa, serta peningkatan pelayanan desa. Adanya Dana Desa maka pembangunan desa, perekonomian desa, dan pelayanan desa akan mencapai tujuan yang optimal. Dana desa harus dikelola secara transparan, akuntabel, partisipatif, tertib, dan disiplin, mengingat jumlah dana desa yang cukup besar (Umar, 2018)

Peraturan Menteri Desa, Pembangunan Daerah Tertinggal, dan Transmigrasi Republik Indonesia Nomor 21 Tahun 2015 pasal 1 ayat 2 tentang Dana Desa adalah dana yang bersumber dari Anggaran Pendapatan dan Belanja Negara yang diperuntukan bagi Desa yang ditransfer melalui Anggaran Pendapatan dan Belanja Daerah Kabupaten atau kota yang digunakan untuk mendanai penyelenggaraan pemerintah, pelaksanaan pembangunan, pembinaan kemasyarakatan, dan pemberdayaan masyarakat. Seiring dengan perkembangan akuntansi sektor publik, pertanggungjawaban kepada masyarakat atas kinerja pemerintahan menjadi tuntutan umum bagi pemerintah. Fenomena kualitas laporan keuangan desa merupakan suatu hal unik untuk dikaji lebih lanjut. Perkembangan akuntansi sektor publik di Indonesia, maka wujud pertanggungjawaban kepada masyarakat desa adalah tuntutan umum bagi pemerintahan desa. Kasus yang terjadi di desa adalah korupsi dana desa, dikarenakan kepala desa menyalahgunakan dana desa tersebut untuk kepentingan pribadi, maka semua kegiatan yang dilakukan dalam lembaga pemerintahan pusat, pemerintahan daerah, dan pemerintahan desa akan diukur dalam hal akuntabilitas (Haliah, 2019). Maka diperlukan akuntabilitas dalam mengelola dana desa. Akuntabilitas merupakan tanggung jawab lembaga publik dalam menggunakan dana yang diberikan dari pemerintah pusat secara efektif dan efisien (Dewi, 2019). Menjaga akuntabilitas merupakan aspek penting dari pemerintahan yang memberitahukan masyarakat dan tercermin dalam kualitas laporan keuangan yang dikeluarkan oleh pemerintah daerah (Nirwana, 2018). Informasi - informasi disajikan oleh pemerintah daerah tentunya memperhatikan sebaik - baiknya karena informasi tersebut digunakan untuk pengambilan berbagai keputusan dalam pengendalian. Pentingnya informasi bermanfaat dan memiliki nilai yang digunakan dalam pembuatan keputusan. Informasi bermanfaat adalah informasi yang digunakan oleh para pengguna informasi dalam melakukan pembuatan keputusan.

Laporan keuangan dikatakan berkualitas jika memenuhi empat yaitu pertama relevan. Informasi yang relevan memenuhi karakteristik: pertama memiliki umpan balik, kedua memiliki nilai prediktif, dan ketiga tepat waktu; 
kedua, andal. Laporan keuangan bebas dari salah penyajian yang bersifat menyesatkan dan kesalahan material; ketiga dapat dibandingkan. Laporan keuangan lebih berguna jika dapat dibandingkan dengan laporan keuangan tahun lalu; keempat dapat dipahami. Laporan keuangan harus dapat dipahami oleh pengguna dan dinyatakan dalam bentuk serta istilah yang disesuaikan agar dapat dimenggerti oleh para pengguna. Kualitas laporan keuangan merupakan hasil dari informasi yang akan berguna bagi pengguna dalam pengambilan keputusan setiap desa memiliki kepala desa masing masing, kew ajiban kepala desa untuk mempertanggungjawabkan segala aktivitas dan kegiatan yang ada di desa. Setiap kepala desa memiliki gaya kepemimpinan yang berbeda di setiap desa di kota Denpasar.

Gaya kepemimpinan merupakan metode yang digunakan oleh seorang untuk memepengaruhi perilaku orang lain (Pawirosumarto,2017). Gaya kepemimpinan berpengaruh pada anggotanya untuk dapat mencapai tujuan bersama yang telah disepakati, secara luas diakui dalam literatur bahwa gaya kepemimpinan dapat mempengaruhi sikap dan perilaku karyawan atau bawahannya (Pantouvakis, 2017). Perilaku para anggota organisasi dilihat dari bagaimana pemimpin menerapkan gaya kepemimpinannya yang dapat memotivasi para anggotanya akan memudahkan dalam mencapai tujuannya dan para anggota organisasi dapat menunjukan kinerja yang lebih baik lagi. Konsisten dengan pandangan bahwa kepemimpinan penting dalam lingkungan organisasi, diyakini bahwa gaya kepemimpinan yang baik merupakan hal penting dalam suatu organisasi (Ohemeng, 2018)

Pemerintah pusat telah mengeluarkan dana desa dengan harapan dapat meningkatkan kesejahteraan masyarakat dan memperkuat pembangunan desa. Demi membantu menatausahakan dana desa maka Kementrian Dalam Negeri (Kemendagri) bekerja sama dengan Badan Pengawasan Keuangan dan Pembangunan (BPKP) telah membuat Sistem Informasi Keuangan Desa (SISKEUDES) yang memadai dan dapat diandalkan. Melalui dana desa dengan tugas pemerintah mewujudkan kesejahteraan masyarakat dengan program SISKEUDES yang dapat mempermudah dalam pemantauan penggunaan dan pemanfaatan dana desa. Penggunaan SISKEUDES juga dipertegas dengan himbauan Komisi Pemberantasan Korupsi (KPK) dengan dikeluarkannya surat Nomor B. 7508/01-16/08/2016 tertanggal 31 Agustus 2016 kepada seluruh kepala desa di Indonesia untuk memahami dengan baik dalam menggunakan SISKEUDES dalam pengelolaan keuangan desa. Dalam penggunaan teknologi informasi dalam suatu organisasi dapat membantu desa melaksanakan penyusunan keuangan desa secara efektif dan efisien. Sistem informasi dapat dikatakan efektif yaitu pertama, dalam segi keamanan data. Keamanan data adalah hal yang terpenting dalam teknologi agar terhindar dari tindakan yang disengaja ataupun kesalahan yang dibuat oleh manusia dan tingkat kemampuan sistem informasi berbasis teknologi dalam mengantisipasi illegal access dan kerusakan dalam sistem; kedua, ketepatan waktu. Tingkat kemampuan sistem informasi berbasis teknologi dalam memproses data menjadi laporan baik secara periodik maupun non periodik dalam rentang waktu yang sudah ditentukan, ketiga ketelitian; Ketelitian berpengaruh dengan laporan keuangan yang dibuat, kesalahan terjadi karena adanya kesalahan pencatatan dan kesalahan 
perhitungan, keempat; variasi laporan atau output, kelengkapan isi informasi tidak dilihat dari volumenya saja melainkan informasinya, sistem infromasi berbasis teknologi untuk membuat suatu laporan dengan pengembangan dan perhitungan sesuai dengan kebutuhan berguna bagi pengguna informasi, kelima; relevansi sistem dihasilkan dari produk atau keluaran informasi baik dalam analisis data, pelayanan, maupun penyajian data. (Gayatri, 2018). Teknologi informasi menunjukan layanan yang optimal jika mencapai standar yang telah ditetapkan oleh pemerintah (Patrickson Stewart, 2017).

Gaya kepemimpinan adalah sikap seorang pemimpin yang dipergunakan untuk mempengaruhi bawahannya dan perilaku orang lain. Menurut (Trisnaningsih, 2007). Gaya kepemimpinan merupakan norma perilaku yang digunakan oleh pemimpin dalam mempengaruhi bawahannya atau karyawanya, seorang pemimpin harus menciptakan iklim kerja yang positif yang mampu melakukan perkembangan terhadap anggota serta diharapkan dapat meningkatkan kinerja organisasi. Pemimpin yang akan mengarahkan keberhasilan atau kegagalan suatu organisasi. Gaya pemimpin yang dimiliki oleh pemimpin akan mempengaruhi pada sikap dan perilaku setiap anggotanya dalam menyelesaikan tugasnya sehingga berpengaruh pada hasil organisasinya. Jika gaya kepemimpinannya semakin baik dimana karyawan atau bawahannya terebut, maka semakin mempengaruhi kinerja dari seorang karyawan tersebut.

Gaya Kepemimpinan merupakan cara seorang pemimpin untuk membimbing, memandu, dan mengarahkan sejumlah orang atau bawahannya untuk mencapai tujuan yang sama. Menurut penelitian yang dilakukan (Herniyasa, 2015) menemukan bahwa gaya kepemimpinan berpengaruh positif terhadap laporan keuangan.

$\mathrm{H}_{1}$ : Gaya kepemimpinan berpengaruh positif terhadap kualitas laporan keuangan desa.

Kemajuan teknologi informasi mempunyai pemanfaatan yang luas, seseorang dapat mengakses, mengelola, dan menggunakannya. Pemanfataan teknologi informasi adalah ketersediaan teknologi informasi yang dapat membantu dalam proses pelaporan keuangan (Jauhari, 2019). Dalam pemerintahan desa digunakan untuk mengelola data, memproses, menyusun, menyimpan dan memanipulasi data dalam berbagai cara untuk menghasilkan informasi yang berkualitas. Dengan menafatankan teknologi informasi untuk pemerintahan desa memiliki banyak keunggulan baik dari sisi keakuratan / hasil operasi maupun predikatnya sebagai mesin serbaguna. Komputer sebagai komponen suatu teknologi sebuah alat yang dapat melipatgandakan kemampuan yang dimiliki manusia dan komputer dapat mengerjakan sesuatu yang tidak dapat dikerjakan oleh manusia (Mahayani 2017).

Teknologi informasi merupakan paduan antara komputer dengan teknologi komunikasi. Kompter dapat menyimpan informasi, dan berfungsi sebagai teknologi informasi digunakan sebagai penyebaran informasi. Pemafaatan teknologi informasi adalah sikap atau perilaku dalam menggunakan teknologi informasi untuk menyelesaikan tugas atau meningkatkan kinerja (Siregar, 2017). Hal ini sejalan dengan penelitian sebelumnya Nurillah (2014), dan Andrianto, (2017) menyatakan bahwa pemanfaatan teknologi informasi pada 
kualitas laporan berpengaruh positif. Maka dapat dirumuskan hipotesis sebagai berikut:

$\mathrm{H}_{2:}$ Pemanfaatan teknologi informasi berpengaruh positif terhadap kualitas laporan keuangan desa.

\section{METODE PENELITIAN}

Penelitian ini dilakukan pada Kantor Desa di Kabupaten Denpasar yang berjumlah 27 desa di lingkungan pemerintah kota Denpasar. Lokasi tersebut dipilih karena mendapatkan dana desa sesuai dengan peraturan walikota Denpasar No 11 Tahun 2019 tentang tata cara pembagian dan penetapan rincian dana desa setiap desa tahun anggaran 2019.

Populasi dalam penelitian ini adalah, Kepala desa, sekretaris desa, bendahara desa, Operator IT, BPD, LPM, dan tokoh masyarakat di kota Denpasar yang membuat laporan keuangan yaitu sebanyak 27 Desa. Metode pengumpulan sampel yang digunakan adalah metode purposive sampling. Responden yang dipilih harus mengetahui pengelolaan keuangan dana desa. Responden yang dipilih adalah orang yang melakukan pengelolaan dana desa yaitu kepala desa, sekretaris desa, bendahara desa.

Analisis regresi linear berganda digunakan sebagai teknik analisis data dalam penelitian ini. Model regresi linear berganda dalam penelitian ini ditunjukkan dengan persamaan sebagai berikut.

$Y=\alpha+\beta 1 X 1+\beta 2 X 2+e$.

Keterangan :

$$
\begin{aligned}
& Y=\text { Kualitas Laporan Keuangan Desa } \\
& \alpha=\text { konstanta } \\
& \beta 1=\text { koefisien regresi gaya kepemimpinan } \\
& \beta 2=\text { koefisien regresi pemanfaatan teknologi informasi } \\
& X_{1}=\text { gaya kepemimpinan } \\
& X_{2}=\text { pemanfaatan teknologi informasi }
\end{aligned}
$$

\section{HASIL DAN PEMBAHASAN}

Data responden yang diperoleh dari hasil kuesioner yang telah disebar berdasarkan jenis kelamin dipaparkan dalam Tabel 1, sebagai berikut:

Tabel 1. Distribusi Responden Berdasarkan Perbedaan Jenis Kelamin Pada Seluruh Desa Kota Denpasar

\begin{tabular}{lll}
\hline Jenis Kelamin & Jumlah Responden & Presentase (\%) \\
\hline Laki - Laki & 124 & 68.9 \\
Perempuan & 56 & 31.1 \\
Jumlah & 180 & 100 \\
\hline
\end{tabular}

Sumber: Data Penelitian, 2019

Tabel 1, menunjukan bahwa jumlah responden seluruh desa di kota Denpasar, dominan berjenis laki - laki sebanyak 124 orang dengan persentase 68,9 persen dari total jumlah responden. Sedangkan jumlah responden perempuan sebanyak 56 orang dengan persentase 31,1 persen dari total jumlah responden.

Faktor usia seseorang dapat menunjang kegiatan organisasi pemerintahan dalam menghasilkan organisasi yang berkualitas. Dengan umur yang produktif 
yang dimiliki akan membantu dalam pencapaian organisasi. Data responden yang diperoleh dari hasil kuesioner yang telah disebar berdasarkan tingkat usia dipaparkan dalam Tabel 2, sebagai berikut:

Tabel 2. Distribusi Responden Berdasarkan Tingkat Usia Pada Seluruh Desa Kota Denpasar

\begin{tabular}{ccc}
\hline Tingkat Umur (Tahun) & Jumlah (Orang) & Persentase $(\%)$ \\
\hline $20-25$ & 23 & 12.78 \\
$26-30$ & 33 & 18.33 \\
$31-35$ & 13 & 7.22 \\
$36-40$ & 30 & 16.67 \\
$41-45$ & 17 & 9.44 \\
$46-50$ & 29 & 16.11 \\
$>50$ & 35 & 19.44 \\
Jumlah & 180 & 100 \\
\hline
\end{tabular}

Sumber: Data Penelitian, 2019

Tabel 2, menunjukan bahwa responden yang berusia 20 - 25 tahun adalah sebanyak 23 orang. Responden yang berusia 26 - 30 tahun adalah sebanyak 33 orang. Responden yang berusia 31 - 35 tahun adalah sebanyak 13 orang. Responden yang berusia 36 - 40 tahun adalah sebanyak 30 orang. Responden yang berusia $41-45$ tahun adalah sebanyak 17 orang. Responden yang berusia 46 - 50 tahun adalah sebanyak 29 orang. Responden yang berusia $>50$ Tahun adalah sebanyak 35 orang. Hal ini menunjukan bahwa responden desa di kota Denpasar dominan adalah yang berusia 50 tahun ke atas dengan persentase 19,44 persen.

Data responden yang di peroleh dari hasil kuesioner yang telah disebar seluruh desa Kota Denpasar berdasarkan tingkat pendidikan dipaparkan dalam Tabel 3, sebagai berikut:

Tabel 3. Distribusi Responden Berdasarkan Tingkat Pendidikan Pada Seluruh Desa Kota Denpasar

\begin{tabular}{lll}
\hline Tingkat Pendidikan & Jumlah (Orang) & Persentase (\%) \\
\hline SMA & 84 & 46.67 \\
D3 & 6 & 3.33 \\
S1 & 86 & 47.78 \\
S2 & 3 & 1.67 \\
S3 & 1 & 0.56 \\
Jumlah & 180 & 100 \\
\hline
\end{tabular}

Sumber: Data Penelitian, 2019

Tabel3, Menunjukan bahwa responden yang memiliki pendidikan terakhir SMA adalah sebanyak 84 orang. Responden yang memiliki pendidikan terakhir D3 adalah sebanyak 6 orang. Responden yang memiliki pendidikan terakhir S1 adalah sebanyak 86 orang. Responden yang memiliki pendidikan terakhir S2 adalah sebanyak 3 orang. Responden yang memiliki pendidikan terakhir S3 adalah sebanyak 1 orang. Hal ini menunjukan bahwa pendidikan terakhir responden pada seluruh desa di Kota Denpasar paling dominan adalah lulusan S1 yakni sebanyak 47.78 persen.

Data responden yang diperoleh dari hasil kuesioner yang telah disebarkan berdasarkan masa kerja responden dipaparkan dalam Tabel 4, sebagai berikut: 
Tabel 4. Distribusi Responden Berdasarkan Masa Kerja Pada Seluruh Desa Kota Denpasar

\begin{tabular}{lll}
\hline Masa Kerja Responden & Jumlah (Orang) & Persentase (\%) \\
\hline 1-10 Tahun & 154 & 85.56 \\
11-20 Tahun & 18 & 10.00 \\
21-30Tahun & 7 & 3.89 \\
>30 Tahun & 1 & 0.56 \\
Jumlah & 180 & 100 \\
\hline
\end{tabular}

Sumber: Data Penelitian, 2019

Tabel 4, menunjukan bahwa sebagaian besar responden pada seluruh desa di kota Denpasar memiliki masa kerja 1 hingga 10 tahun dengan jumlah responden sebanyak 154 orang dengan persentase 85,56 persen dari jumlah responden. Kemudian responden yang memiliki masa kerja 11 sampai 20 tahun dengan jumlah responden sebanyak 18 orang dengan persentase 10,00 persen dari jumlah responden. Responden yang memiliki masa kerja 21 sampai 30 tahun dengan jumlah 7 orang dengan persentase 3,89 persen dari jumlah responden dan responden yang memiliki masa kerja lebih dari 30 tahun sebanyak 1 orang dengan persentase 0,56 dari jumlah responden. Hal ini menunjukan bahwa mayoritas responden seluruh desa di kota Denpasar memiliki masa kerja 1 sampai 10 tahun.

Uji statistik deskriptif menyajikan informasi dari suatu data yang dilihat dari jumlah sampel, nilai minimum, nilai maksimum, nilai rata - rata, dan devisiasi standar dari masing-masing variabel. Hasil dari statistik deskriptif dapat dilihat pada Tabel 5, berikut :

Tabel 5. Hasil Analisis Statistik Deskriptif

\begin{tabular}{|c|c|c|c|c|c|}
\hline & $\mathrm{N}$ & Minimum & Maximum & Mean & Std. Deviation \\
\hline Kepemimpinar & 180 & 11.00 & 20.00 & 14.9944 & 2.42311 \\
\hline
\end{tabular}

(X1)

$\begin{array}{llllll}\text { Pemanfaatan Teknologi } & 180 & 17.00 & 24.00 & 21.5500 & 2.28249\end{array}$

Informasi (X2)

$\begin{array}{lllllll}\text { Kualitas } & \text { Laporan } & 180 & 21.00 & 32.00 & 27.7056 & 2.65249\end{array}$

Keuangan Desa $(Y)$

Sumber: Data Penelitian, 2019

Variabel gaya kepemimpinan memiliki nilai rata - rata sebesar 14,9944. Artinya adanya kecendrungan nilai rata - rata mendekati minimum. Hal ini berarti jawaban atas pernyataan yang terdapat pada kuesioner variabel gaya kepemimpinan, mengidentifikasikan bahwa gaya kepemimpinan yang diterapkan di desa cenderung rendah. Nilai deviasi standar gaya kepemimpinan adalah sebesar 2,4231. Nilai ini cenderung lebih rendah dibandingkan dengan rata - rata. Hal ini menunjukan bahwa penyebaran data dan jawaban responden pada pernyataan gaya kepemimpinan dapat dinyatakan sudah merata. 
Variabel pemanfaatan teknologi informasi memiliki nilai rata - rata sebesar 21,55 . Artinya adanya kecenderungan nilai rata - rata mendekati maksimum. Hal ini berarti jawaban atas pernyataan yang terdapat pada kuesioner variabel pemanfaatan teknologi informasi, mengidentifikasikan bahwa pemanfataan teknologi informasi yang diterapkan di desa cenderung tinggi. Nilai deviasi standar pemanfataan teknologi informasi adalah sebesar 2,28249. Nilai ini cenderung lebih rendah dibandingkan dengan rata - rata. Hal ini menunjukan bahwa penyebaran data dan jawaban responden pada pernyataan pemanfataan teknologi iformasi dapat dinyatakan sudah merata.

Variabel kualitas laporan keuangan desa memiliki nilai rata - rata sebesar 27,7056 , artinya adanya kecenderungan nilai rata - rata mendekati maksimum. Hal ini berarti jawaban atas pernyataan yang terdapat pada kuesioner variabel kualitas laporan keuangan desa, mengidentifikasikan bahwa kualitas laporan keuangan desa yang diterapkan di desa cenderung tinggi. Nilai devisiasi standar pemanfataan teknologi informasi adalah sebesar 2.65249. Nilai ini cenderung lebih rendah dibandingkan dengan rata - rata. Hal ini menunjukan bahwa penyebaran data dan jawaban responden pada pernyataan kualitas laporan keuangan desa dapat dinyatakan sudah merata.

Pengujian dalam analisis linier berganda pada penelitian ini digunakan untuk menganalisis pengaruh gaya kepemimpinan $\left(X_{1}\right)$, pemanfaatan teknologi informasi $\left(\mathrm{X}_{2}\right)$ pada kualitas laporan keuangan desa $(\mathrm{Y})$. perhitungan koefisien regresi linier berganda dilakukan dengan menggunakan Software SPSS version 25. Pada Tabel 6, menunjukan hasil dari analisis regresi linier berganda sebagai berikut:

Tabel 6. Hasil Analisis Regresi Linier Berganda

\begin{tabular}{|c|c|c|c|c|c|}
\hline \multirow[t]{2}{*}{ Model } & \multicolumn{2}{|c|}{$\begin{array}{l}\text { Unstandardized } \\
\text { Coefficients }\end{array}$} & $\begin{array}{l}\text { Standardized } \\
\text { Coefficients }\end{array}$ & \multirow[t]{2}{*}{$\mathrm{t}$} & \multirow[t]{2}{*}{ Sig. } \\
\hline & $\mathrm{B}$ & Std. Error & Beta & & \\
\hline (Constant) & 12.870 & 1.736 & & 7.415 & 0.000 \\
\hline Gaya Kepemimpinan (X1) & 0.148 & 0.070 & 0.135 & 2.101 & 0.037 \\
\hline $\begin{array}{ll}\text { Pemanfaatan } & \text { Teknologi } \\
\text { Informasi }(X 2) & \end{array}$ & 0.586 & 0.075 & 0.504 & 7.834 & 0.000 \\
\hline Adjusted R Square & 0.293 & & & & \\
\hline $\mathrm{F}$ & 38.119 & & & & \\
\hline Sig. & 0.000 & & & & \\
\hline
\end{tabular}

Sumber: Data Penelitian, 2019

Berdasarkan hasil analisis regresi linier berganda pada Tabel 2, maka dapat disusun persamaan regresi sebagai berikut:

$$
\mathrm{Y}=12,870+0,148 \mathrm{X}_{1}+0,586 \mathrm{X}_{2}
$$

Koefisien determinasi $\left(\mathrm{R}^{2}\right)$ digunakan untuk mengetahui atau mengukur kemampuan model dalam menerangkan variasi variabel independen. Menggunakan nilai adjusted $\mathrm{R}^{2}$ untuk mengevaluasi model regresi yang terbaik, nilai koefisien determinasi yang rendah dapat dikatakan kemampuan variabel independen dalam menjelaskan variasi variabel dependen sangat terbatas, sedangkan jika nilai koefisien determinasi yang tinggi dapat dikatakan kemampuan variabel independen dalam memberikan semua informasi yang dibutuhkan untuk memprediksikan variasi variabel dependen. Hasil uji koefisien determinasi dalam penelitian ini menunjukan nilai determinasi sebesar 0,293 
mempunyai arti sebesar 29,3\% variasi Kualitas Laporan Keuangan Desa dipengaruhi oleh variasi Gaya Kepemimpinan, Pemanfaatan Teknologi Informasi sedangkan sisanya 70,7\% dijelaskan oleh faktor lain yang tidak dimasukkan kedalam model.

Uji kelayakan model atau uji $\mathrm{F}$ digunakan untuk tahapan awal mengidentifikasikan model regresi yang dikatakan layak atau tidak layaknya pengaruh gaya kepemimpinan, pemanfaatan teknologi informasi, pada kualitas laporan keuangan desa sebagai variabel dependen. Hasil uji regresi dikatakan layak jika memiliki nilai signifikansi uji F kurang dari 0,05. Hasil uji kelayakan pada model penelitian ini dapat dilihat pada Tabel 7, sebagai berikut:

Tabel 7. Hasil Uji F

\begin{tabular}{lllllll}
\hline Model & & $\begin{array}{l}\text { Sum of } \\
\text { Squares }\end{array}$ & $d f$ & Mean Square & F & Sig. \\
\hline 1 & Regression & 379.141 & 2 & 189.570 & 38.119 & $.000^{\text {a }}$ \\
& Residual & 880.254 & 177 & 4.973 & & \\
& Total & 1259.394 & 179 & & & \\
\hline
\end{tabular}

Sumber: Data Penelitiam, 2019

Hasil uji kelayakan model atau uji $\mathrm{F}$ yang telah disajikan pada Tabel 7, dapat dikatakan bahwa nilai F sebesar 38,119 dengan signifikansi sebesar 0,000. Hal tersebut menunjukan bahwa signifikansi pada uji $\mathrm{F}$ lebih kecil dari 0,05, maka dapat disimpulkan bahwa model regresi pada penelitian ini layak digunakan dalam menjelaskan pengaruh gaya kepemimpinan, pemanfaatan teknologi informasi pada kualitas laporan keuangan desa.

Uji Hipotesis dilakukan untuk menguji hipotesis yang menyatakan bahwa pengaruh gaya kepemimpinan, pemanfaatan teknologi informasi pada kualitas laporan keuangan desa. Kriteria pengujian untuk menjelaskan interpretasi pengaruh antar masing - masing variabel, apabila nilai signifikansi kurang dari 0,05 maka $\mathrm{H}_{0}$ ditolak dan $\mathrm{H}_{1}$ diterima.

Hasil analisis pengaruh Gaya Kepemimpinan pada Kualitas Laporan Keuangan Desa diperoleh nilai signifikansi sebesar 0,037 dengan nilai koefisien regresi sebesar 0,148. Maka nilai signifikansi pada gaya kepemimpinan sebesar 0,037 libih kecil dari 0,05 menyatakan bahwa $\mathrm{H}_{0}$ ditolak dan $\mathrm{H}_{1}$ diterima. Hasil ini memiliki arti bahwa Gaya Kepemimpinan Berpengaruh positif pada Kualitas Laporan Keuangan Desa.

Hasil analisis pengaruh Pemanfaatan Teknologi Informasi pada Kualitas Laporan Keuangan Desa diperoleh nilai signifikansi sebesar 0,000 dengan nilai koefisien regresi sebesar 0,586. Maka nilai signifikansi pada pemanfaatan teknologi informasi sebesar 0,000 libih kecil dari 0,05 menyatakan bahwa $\mathrm{H}_{0}$ ditolak dan $\mathrm{H}_{1}$ diterima. Hasil ini memiliki arti bahwa Pemanfaatan Teknologi Informasi Berpengaruh positif pada Kualitas Laporan Keuangan Desa.

Gaya Kepemimpinan adalah sikap bagaimana seorang pemimpin memberi pengaruh kepada anggotanya untuk mencapai tujuan bersama. Gaya kepemimpinan yang baik dapat memberikan motivasi anggotanya atau bawahannya menjadikan organinasi lebih mudah dalam mencapai tujuan dan dapat menunjukan kinerjanya dengan baik. Gaya kepemimpinan yang diterapkan oleh seorang atasan akan mempengaruhi dengan kualitas laporan keuangan (Herniyasa et al., 2015). 
Hasil pengujian penelitian ini menunjukan bahwa gaya kepemimpinan memiliki pengaruh yang positif dan signifikan terhadap kualitas laporan keuangan desa. Artinya semakin baik cara kepala desa memimpin sebuah organisasi, maka akan meingkatkan kualitas laporan keuangan desa yang dikerjakan oleh bawahannya. Hasil ini didukung oleh penelitian sebelumnya yang dilakukan oleh (Herniyasa, 2015) yang menemukan hasil bahwa gaya kepemimpinan berpengaruh positif terhadap kualitas laporan keuangan.

Pemanfaatan Teknologi mendorong organisasi untuk menciptakan keunggulan, informasi yang cepat, tepat, dan akurat maka organisasi dapat mengambil keputusan dengan cepat (Pardani, 2017). Pemanfaatan teknologi yang tepat dan didukung dengan keahlian individu dalam menggunakan teknologi dapat mengingkatkan kinerja perusahaan maupun kinerja individu, Teknologi informasi memerlukan dana yang besar. Untuk membuat keputusan yang lebih informative, pengembangan sistem informasi perlu memiliki pemahaman yang lebih baik.

Hasil pengujian penelitian ini menunjukan bahwa pemanfaatan teknologi informasi memiliki pengaruh yang positif dan signifikan terhadap kualitas laporan keuangan desa. Artinya, semakin baik pemanfaatan teknologi informasi yang dilakukan di desa kota Denpasar, kualitas pengambilan keputusan terhadap laporan keuangan desa semakin maksimal dan tepat. Hasil penelitian ini didukung dengan penelitian sebelumnya yang dilakukan oleh Nurillah (2014), dan Andrianto, (2017) menyatakan bahwa pemanfaatan teknologi informasi pada kualitas laporan keuangan berpengaruh positif.

\section{SIMPULAN}

Gaya Kepemimpinan berpengaruh positif dan signifikan Terhadap Kualitas Laporan Keuangan Desa. Maka semakin baik cara kepala desa memimpin sebuah organisasi, maka akan meingkatkan kualitas laporan keuangan pada desa yang dikerjakan oleh bawahannya. Pemanfaatan Teknologi Informasi berpengaruh positif dan signifikan Terhadap Kualitas Laporan Keuangan Desa. Artinya semakin baik pemanfaatan teknologi informasi yang dilakukan oleh desa di kota Denpasar, maka kualitas pengambilan keputusan terhadap laporan keuangan desa semakin maksimal dan penyusunan laporan keuangan tepat waktu dan efisien.

Berdasarkan hasil dari penelitian dan hasil penelitian maka saran yang dapat yang diberikan adalah, diharapkan seluruh perangkat desa dalam rangka memperoleh laporan keuangan desa dan perangkatnya mengerjakan laporan keuangan dengan baik. Saran bagi kepala desa agar mengawasi atau ikut serta dalam penyusunan laporan keuangan agar meminimalisirkan kesalahan dalam pembuatan laporan keuangan dikarenakan gaya kepemimpinan yang diterapkan dalam organisasi secara tidak langsung akan mempengaruhi kinerja bawahannya. Didukung dengan teknologi memudahkan dalam pembuatan laporan keuangan maka adanya teknologi yang di terapkan di desa maka penyusunan laporan keuangan dapat tepat waktu. Saran bagi desa dalam teknologi menyediakan komputer yang cukup dan baik dalam penyusunan laporan keuangan. Saran yang dapat diberikan berdasarkan dari hasil penelitian ini untuk peneliti selanjutnya diharapkan menambah variabel bebas yaitu 
sumber daya manusia, sistem pengendalian intern, dan badan usaha milik desa (BUMDES). Menggunakan lokasi penelitian di kabupaten lain, dan menambahkan kelurahan sebagai sampel baru dalam penelitian selanjutnya.

\section{REFERENSI}

Andrianto, E. (2017). Pengaruh Kapasitas Sumber Daya Manusia, Pemanfaatan Teknologi Informasi, Dan Sistem Pengendalian Intern Pemerintah Terhadap Kualitas Laporan Keuangan Pemerintah Daerah Dengan Komitmen Organisasi Sebagai Variabel Moderasi (Studi Empiris Pada Satuan Kerja P. 1-19.

Dewi, N. F., Ferdous Azam, S. M., \& Yusoff, S. K. M. (2019). Factors influencing the information quality of local government financial statement and financial accountability. Management Science Letters, 9(9), 1373-1384. https://doi.org/10.5267/j.msl.2019.5.013

Gayatri, G., \& Latrini, M. Y. (2018). Efektivitas Penerapan Sistem Keuangan Desa dan Kualitas Laporan Keuangan Desa. Jurnal Ilmiah Akuntansi Dan Bisnis, 113. https://doi.org/10.24843/JIAB.2018.v13.i02.p05

Haliah, \& Nirwana. (2019). The development of good governance model for performance improvement. International Journal of Excellence in Government, 1(1), 21-36. https:// doi.org/10.1108/ijeg-09-2018-0004

Herniyasa, H., Fadilah, S., \& Nurcholisah, K. (2015). Pengaruh Penerapan Gaya Kepemimpinan Dan Good University Governance terhadap Kualitas Laporan Keuangan ( Survey Pada Politeknik Negeri Bandung ). 174-182.

Jauhari, H., Sari, Y., \& Dewata, E. (2019). Implementation of Good Governance, Utilization of Information Technology and Reliability of Government Financial Statement. Journal of Accounting and Strategic Finance, 2(2), 117-126. https://doi.org/10.33005/jasf.v2i2.59

Mahayani, N. P. L., Sulindawati, N. L. G. E., \& Marvilianti Dewi, P. E. D. (2017). Pengaruh Kualitas Sumber Daya Manusia Bidang Akuntansi, Sistem Pengendalian Internal Dan Pemanfaatan Teknologi Informasi Terhadap Kualitas Laporan Keuangan (Studi Pada Koperasi Simpan Pinjam Di Kabupaten Jembrana). E-Journal S1 Ak Universitas Pendidikan Ganesha, 8(2), $1-11$.

Nirwana, \& Haliah. (2018). Determinant factor of the quality of financial statements and performance of the government by adding contextual factors. Asian Journal of Accounting Research, 3(1), 28-40. https://doi.org/10.1108/ajar-06-2018-0014

Nurillah, A. S., \& Muid, D. (2014). Pengaruh Kompetensi Sumber Daya Manusia, Penerapan Sistem Akuntansi Keuangan Daerah (Sakd), Pemanfaatan Teknologi Informasi, Dan Sistem Pengendalian Intern Terhadap Kualitas Laporan Keuangan Pemerintah Daerah (Studi Empiris Pada SKPD Kota Depok). Diponegoro Journal Of Accounting, 3(2), 1-13.

Ohemeng, F. L. K., Amoako-Asiedu, E., \& Obuobisa Darko, T. (2018). The relationship between leadership style and employee performance. International Journal of Public Leadership, 14(4), 274-296. https://doi.org/10.1108/ijpl-06-2017-0025

Pantouvakis, A., \& Patsiouras, C. (2017). Exploring the role of Leadership Style on the Service Quality - Customer Satisfaction link: Evidence from a B2B 
environment. International Journal of Quality and Service Sciences, 8(1), 88-101. Pardani, K. K., \& Damayanthi, I. G. A. E. (2017). Pengaruh Pemanfaatan Teknologi, Partisipasi Pemakai, Manajemen Puncak Dan Kemampuan Pemakai Terhadap Efektivitas Sistem Informasi Akuntansi. E-Jurnal Akuntansi Universitas Udayana, 19(3), 2234-2261.

Patrickson Stewart, S. G., \& Newman, N. (2017). User services in the digital environment: Implications for academic libraries in the English-speaking Caribbean. Library Review, 66(4-5), 213-234. https://doi.org/10.1108/LR-072016-0058

Pawirosumarto, S., Sarjana, P. K., \& Gunawan, R. (2017). The effect of work environment, leadership style, and organizational culture towards job satisfaction and its implication towards employee performance in Parador hotels and resorts, Indonesia. International Journal of Law and Management, 59(6), 1337-1358. https://doi.org/10.1108/IJLMA-10-2016-0085

Siregar, S. H. (2017). Pengaruh Kapasitas Sumber Daya Manusia, Pemanfaatan Teknologi Informasi dan Pengendalian Intern Akuntansi terhadap Kualitas Laporan Keuangan Kementerian/Lembaga dengan Komitmen Organisasi sebagai Variabel Pemoderasi pada Satuan Kerja di Lingkungan KPPN Ba. Universitas Sumatera Utara.

Trisnaningsih, S. (2007). Independensi auditor dan komitmen organisasi sebagai mediasi pengaruh pemahaman. Universitas Pembangunan Nasional, 7, 1-56. https://doi.org/10.1590/S0104-14282003000200006

Umar, H., Usman, S., \& Purba, R. B. R. (2018). The Influence Of Internal Control And Competence Of Human Resources On Village Fund Management And The Implications On The Quality Of Village Financial Reports. International Journal of Civil Engineering and Technology, 9(7), 1523-1531. 